\title{
"For We ascend in holiness and do not descend." Jewish ultra-Orthodox women's agency through their discourse about media
}

\author{
Rivka Neriya-Ben Shahar \\ The Department of Communication, Sapir Academic College, D.N. Hof Ashkelon, Israel
}

\begin{abstract}
"Permission" and "prohibition" are key terms in Jewish religious discourse. For generations they have dominated as part of the primarily male, rabbinic discourse in talmudic literature. This paper will show that men no longer hold the monopoly on these terms because contemporary Israeli ultra-Orthodox women include them in their daily conversation in multiple and varied ways. The study examines exposure patterns and perceptions of 42 ultra-Orthodox women toward sectarian and general mass media. In responses to detailed questionnaires, the words "prohibited," "forbidden" and "a boundary" constantly recur along with a variety of negatives, such as "not permitted," "not allowed" and "not kosher".

This paper argues that in describing their uses of and perceptions toward mass media, ultra-Orthodox women have adopted terminology borrowed from what was previously a primarily maledominated conversation. Some might argue that these women are simply working within the bounds of ultra-Orthodox law which they accept as universally applicable; or perhaps that these women are simply reflecting words used by their husbands or rabbis. However, this study argues that their adoption of these terms indicates they are exercising their own agency. With a combined religious and secular education, and work that is primarily outside the house, many of them are the principal breadwinners in their homes. I suggest that this discourse is a part of their highly intelligent navigation of their simultaneous roles as both gatekeepers and change agents.
\end{abstract}

\section{Introduction}

This article will focus on the relationship between gender, religion and discourse. Ostensibly, obedience by ultra-Orthodox women to religious discourse should maintain their marginality. However, we find that clever manipulation of religious discourse by these women, enables them to negotiate marginality and create agency for themselves. I will argue that male use of religious discourse is exclusionary, enforcing obedience while causing and maintaining marginality, and yet, the same discourse, when used by women, can lead to their own inclusion and agency. Religious discourse can 
simultaneously be a point of connection and separation, depending on the user and the situation.

This article shows that: (1) ultra-Orthodox women use various halakhic terms from multiple sources; (2) This use allows them entry into spaces from which they had previously been excluded. The sacred texts and spaces become part of their daily navigation of worldly spaces such as mass media. Thus, (3) the women's day-to-day discourse using halakhic terminology combines their perceptions of sacred and profane, reflecting the religion as they live it. Following a brief description of the ultra-Orthodox community and its women, the literature review will describe the power of discourse, agency among religious women, as well as insights into the theory of "lived religion."

\section{The ultra-Orthodox community}

Ultra-Orthodox Jews in Israel (hereafter: ultra-Orthodox) comprise a community committed to rigid observance of religious laws through unquestioning faith, strict religious behaviour and obedience to the authority of its leaders (Caplan 2007). Their commitment to Torah study (Silber 1992; El-Or 1994) and socio-political circumstances have led to their becoming an intellectual "society of scholars" (Friedman 1991; Stadler 2009, 2012). The ultra-Orthodox are a minority group, comprising approximately $12 \%$ of Israel's population (Cahaner, Malach, and Choshen 2017). However, their multiple external connections challenge the term "enclave culture," derived from Cultural Theory (Douglas 1966, 1970, 2005; Marty and Appleby 1991; Almond, Appelby, and Sivan 2003; Inbari 2016). Ultra-Orthodox women are responsible for their families of, on average, seven children, and supply most of the practical and social needs of their communities. They have an average of 14 years of schooling and are mostly the primary earners in full-time jobs outside their homes, while their husbands devote their time to religious studies.

\section{The power of the discourse}

"Discourse is the power which is to be seized," wrote Foucault $(1981,53)$. He argued that discourse has a complicated process of control, because discourse is part of the control system, while being controlled itself. The control process includes definitions and conditions which comprise the rules, while the discourse itself simultaneously differentiates and enables discrimination. This differentiation also includes processes of exclusion, the most familiar aspect of which is prohibition. "We know quite well that we do not have the right to say everything, that we cannot speak of just anything in any circumstances whatever, and that not everyone has the right to speak of anything whatever." (Foucault 1981, 52). Among the traditional ultra-Orthodox community, men dominate discourse. The procedures of exclusion are an important element of the distribution of knowledge within a society. Systems of education, which are supposedly responsible for the distribution of knowledge, might achieve the exact opposite: "Any system of education is a political way of maintaining or modifying the appropriation of discourses, along with the knowledges and powers which they carry" (Foucault 1981, 64). 
A somewhat different way of functioning is that of the "Societies of discourse", which preserve or produce discourses, but in order to make them circulate in a closed space, distributing them only according to strict rules, and without the holders being dispossessed by this distribution. (Foucault 1981, 62-63)

This articulation is an apt description of the "Beit midrash" system, a space opens only to men, where they create and preserve the discourse while carefully controlling the procedures of distribution and exclusion. As part of a powerful system that controls religious knowledge, it is here that men determine and decide what women are permitted or prohibited to study and know.

\section{Agency among religious women}

This study follows scholars who have engaged deeply and ethnographically with contemporary religious women. I rely particularly on the ideas of Abu-Lughod (1990, 1991, 2013), Griffith (1997) and Mahmood (2005). Abu-Lughod argued that we actually need to see the experiences of religious women, rather than thrust Western-feminist choices upon them. Griffith found that evangelical women experience agency, liberation, and empowerment through their religious practices. Mahmood (2005, 17-18) defined agency "not simply as a synonym for resistance to social norms, but as a modality of action that specific relations of subordination create and enable." Avishai (2008) argued that religious women are authentic subjects who choose their religious conduct, experiences and complex identity. They expanded on feminist views of agency by showing its multiple forms and modalities and suggested changing the accepted view that obedience/empowerment and surveillance/independence are dichotomies. Feminist anthropological studies about ultra-Orthodox women show that they use their religious studies (El-Or 1994) and mediated popular psychology to create and reinforce their position in hierarchies in their gendered communities (Fader 2009, 2013), and that religious rigour and discipline earn them superiority in their communities (Jacobson 2006).

The women's discourse helps demonstrate their agency, while their culture enables them to use various strategies of language, such as the sophisticated creation of code, defined as "a set of signals - words, forms, behaviours, signifiers of some kind - that protect the creator from the consequences of openly expressing particular messages" (Radner and Lanser 1993, 3). The primary code used by ultra-Orthodox women in their responses in this article is one of appropriation, designating

strategies that involve adapting to feminist purposes, forms or materials normally associated with male culture [...] What we are calling appropriation encompasses some aspects of [...] symbolic inversion [...], in which a patriarchally designated feminine position is repeated with exaggeration in order to expose it. (Radner and Lanser 1993, 10)

The data will show the sophisticated use made by ultra-Orthodox women of religious discourse, to shed light on insights of symbolic inversion. Foucault (1981) wrote that

we are all here in order to show you that discourse belongs to the order of laws, that we have long been looking after its appearances; that a place has been made ready for it, a place which honors it but disarms it. (51-52)

These women use halakhic terminology as a part of this code appropriation. Their use of the male halakhic discourse outside its traditional Jewish contexts of kashrut, Shabbat, and 
niddah (menstruation), removes it from its exclusive male ownership and facilitates agency for the women themselves, gaining them entry into spaces from which they would otherwise be excluded. However, the significance of this agency is not only the use of the discourse but, rather, their sophisticated appropriation of the codes, modified to function within the world they occupy. I see this usage as symbolic inversion, "defined as any act of expressive behaviour which inverts, contradicts, abrogates, or [...] presents an alternative to commonly held cultural codes, values and norms be they linguistic, literary or artistic, religious, or social and political" (Babcock 1978, 14).

I might have expected to receive halakhic answers in a questionnaire that focused on ultra-Orthodox women and issues of Shabbat or kashrut. Since these women are likely to be more knowledgeable about these practical commandments than their husbands, they might have given highly detailed answers regarding halakhic facts and stringencies. However, as I will show below, the questionnaire that was used for this study focused on media use, not a central halakhic issue dealt with by the old sages. This leads me to read the women's responses as demonstrating their internalization of the idea that "everything is halakhic" within the ultra-Orthodox community.

\section{Lived and everyday religion}

The "lived religion" theory calls for a transition from studies about religion as institutions, beliefs, norms and doctrines, toward daily practices of ordinary people (Ammerman 2007; McGuire 2008) who experience liberation, empowerment and deliverance through religious practices (Griffith 1997). It could be summarized by Orsi's (2005) insight that, "Religion cannot be understood apart from its place in the everyday lives, preoccupations and commonsense orientations of men and women" (167). Since everyday lives are much more complicated than social science categories and divisions, Asad (2003) argues that the religious and secular are not hard categories, and that the sacred and secular are interdependent. Orsi concurs, writing that,

sacred and profane are never distinct [...] but are braided in people's every-day experience [...] We no longer speak of sacred or profane but of a helix, a twisting of sacred and profane around each other through the movement of people's days, the contingencies of their social circumstances, and the dynamics of their relationships. (Orsi 2012, 154)

The everyday lives of religious people obviously include a combination of religious and non-religious discourse. Casanova $(2010,25)$ claimed that religion itself is "a discursive reality [...] a system of classification of reality." Based on Schutz (1962), who pointed to the importance of everyday reality and ordinary conversation, Wuthnow (2011) argued that

religious discourse is clearly a social practice-patterned by the social institutions in which it is learned and in which it is practiced, explicitly taught, and implicitly modeled so that practitioners adhere to commonly accepted rules governing the practice, internalized so that these rules often do not require conscious deliberation, and yet observable in the structure and content of discourse itself. (7)

He also found that the daily discourse of religious people is cultural, where "values and beliefs acquire sufficient meaning to guide behaviour and to provide a template for selfunderstanding" (9). 
The religious discourse surrounding media is an important part of the creation of cultural meaning through decision making about its use (Stout 2001). Campbell (2010) stresses the discourses used by religious communities around media:

The process of negotiation involves shaping both the technology and the language used to describe it within distinctive ways. Thus, how religious user communities talk about their technology is not simply descriptive, it is also an active process performing a variety of roles [...] Language has power, and in the case of the relationships of a religious community to technology it creates a platform for communal acceptance, boundary setting and ideological promotion. (Campbell 2010, 161)

This review enables us to see that the discourse has complicated and multiple systems of power and control within a society, providing a platform for selective inclusion and exclusion of people in general, and women in particular, and is an integral part of everyday lived religion. Following Foucault (1981), I am

trying to grasp the forms of exclusion, of limitation, of appropriation [...] showing how they are formed, in response to what needs, how they have been modified and displaced, what constraints they have effectively exerted, to what extent they have been evaded. (70)

Using Foucault's problems as a basis for focusing specifically on contemporary ultraOrthodox women's discourse around media, I asked the following questions: How is the discourse affected when exclusion and limitation become appropriation? How is it modified and how does it function amongst women? Do women use this discourse for negotiation? Following the description of the methods, I analyze the religious discourse of ultra-Orthodox women regarding media and identify the subtle interactions of profane and sacred that comprise this creation of their agency.

\section{Methods}

\section{Population and sample}

From the wide spectrum of the ultra-Orthodox Jewish community, two mainstream groups were chosen for this study, Lithuanian and hasidic ultra-Orthodox Jews (Friedman 1991). In recruiting participants, I relied on the respondents' self-definition (Friedman, Shaul-Mena, and Fogel 2011; Pew Research Center 2013). The study used snowball sampling, a method particularly suited to closed communities (Lee 1993). Snowballs with different demographic characteristics overcame the internal homogeneity of the community.

This study is based on a survey, which employed a combination of qualitative and quantitative methodologies. Questionnaires including open-ended questions were completed by 42 ultra-Orthodox participants. I focused on the women's practices, attitudes and perceptions of media. The questionnaires were completely anonymous and formulated with sensitivity to the language and values of the ultra-Orthodox. Assistants hired from within the community helped in recruiting participants. Participants signed an informed consent form and were compensated for their time.

In terms of the characteristics of the population studied, 90\% (38) of the participants were born in Israel and have a variety of occupations, among them teachers, tax advisers, secretaries, computer programmers, graphic designers. Based on participants selfdefinitions, $64 \%$ are Lithuanian; 12\% are ultra-Orthodox of Eastern origin (Mizrahi/ 
Sephardi, by their definitions); $5 \%$ are hasidic, $5 \%$ consider themselves general ultraOrthodox; $2.5 \%$ newly ultra-Orthodox and the others did not respond to this question. Pariticipants studied in well-known ultra-Orthodox institutions for girls, such as "The Old Seminar"; Lustig; Wolf Seminar and Sharansky Seminar.

Many challenges are associated with research on cloistered communities (Steinmetz and Haj-Yahya 2006; Rier, Schwartzbaum, and Heller 2008). My experience with the ultra-Orthodox was informed by my own biography. My upbringing in a strict nationalist-ultra-Orthodox community and my studies of the ultra-Orthodox community have enabled me to develop a variety of tools for understanding these women "from the inside out" (Hill Collins 1986, 2000; Luhrmann 2012).

Analysis: Based on Foucault's (1969) insight that the attention to the words people choose to use is part of the effort to construct non-hierarchical knowledge, I tried to listen carefully to the women's voices. Since I heard so many halakhic terms, the first step was to mark and count all the words that could be part of the halakhic discourse, such as: "allowed" and "forbidden". The results show that the women mostly used words expressing prohibition. The Wuthnow (2011) critique led to the next step.

Whereas the purpose of many such studies in the literature on the sociology of discourse has been to identify discursive markers, tropes, and categories, the task for scholars of religion would be to utilize these concepts to help make sense of religious symbols, meaning, and behavior. (10)

Therefore, the second step was a qualitative thematic analysis of some of the character types of these women, mining their rich and detailed responses to illustrate their halakhic discourse.

\section{From forbidden to kosher: usage of terminology and quotations by ultra- Orthodox women}

The women used various terms in their responses to express a variety of meanings and subtleties. A number of these terms share the same Hebrew roots, others are different but share a similar association, some of the meanings and context can get lost in translation, so in my discussion, I have utilized the Hebrew terms as well (written in parentheses). The most common term in the responses to the questionnaire was "forbidden" (asur, isur, asru), mentioned 57 times. The second common term was permit/permitted (mutar, lehatir,yatir, heiter) - 44 times; "When necessary" came up 35 times - (letzorekh); holiness (sanctified) - (kadosh, kedusha, kodesh) 30; inappropriate sexual relations (giluy 'arayot) 19; slander (lashon har'a) 19; gossip (rekhilut) 17; impure/impurity (tame, metame, tuma'a) 19; pitfall (mikhshol, yikhashel, lehakhshil) 18; kosher (kasher, hekhsher) 12; boundary (gader) 12; appropriate ( $\left.r a^{\prime} u i\right)$ 9; inappropriate (pasul) 7; transgression (het, avera) 6; bloodshed (shfikhut damim) 4. The Torah's opinion (da'at tora) 4; possible (efshar, but not good) 4; distracted (hese'ah hada'at) 2; a priori (milkhathila) 2; idolatry (avoda zara) 2. Ostensibly it appears that there are multiple mentions of words indicating permission, but they are usually used with a negative to indicate the opposite meaning, such as (not) permitted.

The women's responses included not only terms, but many quotes and references from multiple sources. Their recognition of a wide range of references is reflected in my use here 
of the terms "halakhic discourse" and "religious discourse" interchangeably, since the point of view of the ultra-Orthodox community [hashkafa] focuses particularly on the halakhic aspects of Jewish religious texts. The women's easy use of biblical verses or sages' maxims, while answering a questionnaire about media consumption, indicates that this represents just a fraction of their borrowed knowledge, while the fact that some of their references were partial or inaccurate suggests that they did not use written texts when formulating these responses. The analysis includes researching their cited resources for comparison.

The biblical verses included: "How fair are your tents, O Jacob, thy dwelling, O Israel!" (Numbers, 24:5); "A breed of sinful men" (Numbers, 32: 14); "And let this ruin be under your care" (Isaiah, 3: 6); "Each one helps the other" (Isaiah, 41, 6); “The Lord desires his [servant's] vindication, that he may magnify and glorify [his] teaching" (Isaiah 42: 21); "Let us wipe them out as a nation" (Psalms, 83, 5); "For many are those she has struck dead" (Proverbs, 7: 26); "Behold, I cry out: violence! But am not answered" (Job, 19: 7).

Citations from the Mishna included: "Do not believe in yourself until the day you die" (Avot, 2: 5); "His virtue cancels his flaw" (Avot, 5: 11); "For we ascend in holiness and do not descend" (Shekalim, 6:4). The women had great stores of wisdom - "There is no guardian against unchastity" (Ketubut, 13: 2); "Raba said: 'Sanctify yourself by that which is permitted to you" (Yebamoth, 20a); "Transgresses the injunction against it being seen and found" (Pesachim, 5b); "Balaam lifted up his eyes and he saw Israel dwelling according to their tribes $[. .$.$] the doors of their tents did not exactly face one another" (Baba Bathra, 60a).$ "One must incur martyrdom rather than transgress" (Sanhedrin, 74a); "A scroll of the law which has been written by a min [idol worshipper] should be burnt" (Gittin, 45b); "The Israelites knew that the idols were nonentities, but they engaged in idolatry only that they might openly satisfy their incestuous lusts" (Sanhedrin, 63b); "This nation is distinguished by three characteristics: they are merciful, bashful and benevolent" (Yebamoth, 79a).

The next quotations derive from midrashic literature -

There were some beautiful traits in the character of the Israelites in Egypt, by which alone they merited redemption. They did not change their names [...], neither had they changed their language $[\ldots]$ they eschewed slander, and they were very chaste. (Leviticus Raba, 32);

"When will my deed reach my father's deeds" (Tana Dvei Eliyahu, 25); All Israel are responsible for each other (Safra, 26, 37).

The Siddur, the Jewish prayer book, was another resource - "Bringing about renewal" (The morning prayer); "My God, The soul that You have placed within me is pure" (The morning prayers); Blessed is He, our God [...] separated us from those who go astray (The morning prayers); Do not bring us [...] close to challenge (The morning prayers); "The Torah will never be abrogated, nothing will be added to it or subtracted from it; God will never give another Law" (From the Maimonides' 13 principles of faith, usually printed after the morning prayer. The woman wrote the reference in parenthesis).

\section{When forbidden meets need: motive as a guide to character}

In comparison to the previous, technical and quantitative section, which was based on the quantifying of terms and researching of references, this next section is based on qualitative 
thematic analysis, that identifies some defining characteristics of these women. I would argue that their detailed answers provide an illustration of the type of halakhic discourse used by ultra-Orthodox women. I sorted them into groups of gatekeepers and change agents, their names changed to keep their privacy.

\section{The gatekeepers}

Sara (born in 1961, stay-at-home mother of 8, married to a yeshiva scholar) used the term "forbidden" six times in her short responses:

"The [non-ultra-Orthodox] newspapers do not filter things that ultra-Orthodox should not read and hear. It is simply forbidden to hear about some events"; "The [non-ultraOrthodox] radio has songs that we are forbidden to hear"; "There are pictures [on the internet] in immodest commercials, it easily possible to surf to movies with promiscuity that are really forbidden to watch (people told me, I've never seen anything like that)";

[The smartphone] enables simple, and easily accessed surfing of everything on the internet. Immodest pictures ... things that are forbidden to us and for everyone to see and to hear. Without any effort, in such a small device, people can get to sites that the ultra-Orthodox community is forbidden to see and hear, and as I've heard from secular people, it is really forbidden to see.

Lea (born in 1979, stay-at-home mother of 8 , married to a yeshiva scholar) used the term "impure" four times:

"They [the internet and the smartphone] are devices that are mostly used for impure things": "Even ultra-Orthodox newspapers are not really according to our spirit [...] in the secular newspapers it is not possible to read all the impurity and filth that exists there. Even what is not impure, is mostly not interesting"; "All of the impurity in this device (television) is not appropriate for a religious Jew."

Hana, (born in 1977, mother of 6, a secretary, married to a yeshiva scholar) travels the spectrum between purity and holiness to impurity, thus making her analysis more complex than Lea's:

"The ultra-Orthodox newspapers enable us to get updates about holy books": "The radio is an impure device [...] everything includes destruction and poison for every holy thing. Even the religious station ... it is not possible that people hear holy things from an impure device."; "I don't watch this impure device [television]"; "Even the information [on the television] is not according to the spirit of the sages and the outlook of purity"; "The content in these impure devices [...] is not appropriate for us"; "The internet is the most impure device"; "The more you stay safe [from the media devices] the purer your soul remains"; "The soul that God gave us is a pure soul"; "We try to get closer to our holy fathers".

Miriam (born in 1996, single, student) was disturbed especially by the aspects of slander and gossip (lashon hara and rekhilut) in the media:

"The newspapers have lots of gossip": "The radio has lots of slander and gossip": "The [non-ultra-Orthodox] newspapers have lots of slander and gossip"; "One of our 613 commandments is the proscription against speaking/receiving/listening to slander, and the radio does that all the time - they talk slander!! It could destroy our ideal of guarding the tongue"; "The radio talks slander all the time." 
Dina (born in 1970, mother of 10, an accountant who teaches class tax rules in college, married to a yeshiva scholar who writes halakhic texts) represents the religious scholar (talmidat hahamim) among these women. She responded by quoting from a variety of sources:

"We say that God is 'making news"; "The Mishna said, 'until the day you die, do not believe/trust yourself"; "How goodly are thy tents, O Jacob, thy dwellings, O Israel!" (Numbers, 24: 5); "Balaam lifted up his eyes and he saw Israel dwelling according to their tribes [...] the doors of their tents did not exactly face one another" (Baba Bathra, 60a); "The Torah may never be abrogated, nothing may be added to it or subtracted from it; God will never give another Law" (From Maimonides's 13 principles of faith); "Today it's not possible that these devices [television, radio, internet] will be allowed for use. In the exodus they were liberated because they didn't change their language, names and their clothing."

The actual citation from Leviticus Rabba that she is paraphrasing (italics above) is significantly different:

There were some beautiful traits in the character of the Israelites in Egypt, by which alone they merited redemption, they did not change their names, such as Rufus instead of Reuben, Leon in lieu of Simeon, Listus in place of Joseph, or Alexander for Benjamin. Neither had they changed their language, but they retained the Hebrew tongue. They eschewed slander, and they were very chaste. (Levit. Rabba 32).

The reasons for the differences between the language of the source and the various ways it is often misquoted in the ultra-Orthodox community deserves attention elsewhere.

Malka (born in 1986, single, manager of an NPO and an art teacher) writes as a real gatekeeper who defends the community living behind the walls:

"[Television] is open and available to everyone and isn't appropriate for the values and the boundaries of the ultra-Orthodox community [...] who keep themselves apart from various things, so as to guard against communal failure in specific restrictions"; "Some [ultra-Orthodox] radio stations keep specific restrictions such as women singing"; "If the ultra-Orthodox community were to be exposed to things that until now they were distanced from and were strict about not being exposed to, these things would very much affect their daily lives and the ultra-Orthodox community would become the same as other people in the world - without limits, without specific separations that save them. And all of the values and observance of Torah, and the commandments might be loosened":

The nature of people is to be curious and to be swayed [...]. It [...] is hard to stand up against fashion without being affected $[. .$.$] and the ultra-Orthodox man/woman would give up the$ modesty restrictions of their dress code and would wear different clothing that is not always appropriate in the restrictions of halakhic modesty.

Bruria (was born in 1978, mother of 7, teacher at Beit Yaakov seminary [girl's high school], married to a yeshiva scholar) repeatedly uses the terms familiar to every Orthodox Jewish child, for the three forbidden actions for which one must choose martyrdom rather than transgress - adultery, murder and idolatry:

"[Television] radiates a concentration of lust (ta'avtanut) of real adultery, murder and idolatry"; "[The internet] is terrible ... it induces spiritual doubt, and gives easy access to concentrated idolatry, adultery and murder. It is not in vain that the rabbis scream" - "One 
must incur martyrdom rather than transgress. One who allows himself to die by entering the lusts that affect the heart becomes perverted". "Israel didn't perish [... ] just to enable adultery."

Shulamit (born in 1996, single, student) chooses the more pleasant side of the gate. Instead of focusing on the sins, she addresses the holy soul:

"Television is a distracting device that destroys the holy Jewish spirit and soul [...] it distracts from any forms of the pure and holy soul (neshama) of those who keep Jewish Torah and commandments"; "The smartphone is harmful to the pure and holy soul"; "The ultra-Orthodox community needs to preserve its holy nature and impure newspapers breech the walls of holiness"; "[people] are exposed to bad and horrible things as a result of surfing the internet, which harms the holy worship of God"

The gatekeeper group uses religious terminology to explain their attitudes to the media. Their perception of the media resonates with these impressions. It is clear that they view the world through a religious lens, casting all modern and secular media in religious terms, as we will discuss after the next group of narratives.

\section{The change agents}

Tehila (was born 1979, computer programmer, mother of 8, married to yeshiva scholar) struggles daily with the necessity of using the internet for her job, and has an understanding of the pitfalls this presents:

"We have internet at home for the purpose of my job"; "The exposure to the internet and the availability of the smartphone might cause a big exposure to degeneration, contact and failure of serious prohibitions."; "[People] might fail hard [...] but being strict about not bringing these devices home, it's reasonable to assume that they will not fail."; "If you don't really need it [radio], it's better to preserve distance, rather than fail and listen to non-religious stations."

We have internet at home due to the necessities of my job, and we usually discuss how to insure that the family members will not fail by surfing for no [appropriate] reason (lo lezor$e k h$ ). And how to eliminate the children's access to the internet and even to the computer.

Yokheved (born in 1977, mother of 6, a kindergarten teacher, married to a teacher), as did the previous woman, deliberates between her specific needs and the rabbi's prohibitions:

"I use the internet in the public library, for a specific need"; "I would be happy to have an internet connection, but according to the rabbis it is prohibited. Therefore, I have a computer without an internet connection"; "Using the internet for an essential need is important, just as using a car, one needs to know how to use everything, one needs to know how to use and how to be careful"; "We discuss with the children what is permitted and what is prohibited. [...] as Baal Haleshem said: there is no soap created that can clean the prohibited things one has seen".

Rachel (born in 1983, stay-at-home mother of 5 married to a yeshiva scholar) to allow herself to achieve her specific needs, while thoughtfully taking into account the leaders' worldviews:

The radio is an important device that causes us to be integrated into the general life of our country and the wide world. It transfers more or less important information to the public. The ultra-Orthodox radio supplies us with various programs and helps to expose us to 
appropriate content and to not encounter content that oppose the worldview [hashkafa] of the ultra-Orthodox people who listen to them;

"Television is a powerful tool for transferring information with both positive and negative content. [However,] since it is impossible to prevent exposure to negative content it becomes a device I reject";

I use the internet especially for email and I almost never surf. Except for hasidic news on a kosher internet, or for very important information that can't be reached by other options. The internet is a powerful device. Its abilities overtake people's abilities. As much utility as can be derived from it, there are even greater dangers hidden within it, when its use is not controlled. Therefore, in an ultra-Orthodox home, the internet should not be seen or present without a filter. The excess thoughtlessness and lack of control by responsible people underlying the public's right to know can destroy the private lives of individuals and of course the entire community. There is no permit in the world for the gossip you can find there.

The deliberations of these women as change agents can be seen in their combination of negative and positive aspects of different media. Their real needs, reflected in their attempts to utilize media only for appropriate purposes, their understanding of the utilities available, and their recognition of and insights into the dangers inherent in media use, lead them to use religious terminology to reflect their attempts to control these materials.

\section{Discussion and conclusion}

In trying to determine what happens to discourse when exclusion and limitation become appropriation, we see that ultra-Orthodox women, similar to the men, use a variety of halakhic terminology, from multiple and various sources. Their use of biblical verses included not only very well-known verses such as, "How fair are your tents, O Jacob, thy dwelling, O Israel!" ${ }^{2}$ (Numbers, 24: 5), but also more obscure verses like, "For many are those she has struck dead" ${ }^{3}$ (Proverbs, 7: 26) Ultra-Orthodox women are not allowed to study Mishna and Talmud, except Mishna Avot. We might expect to see the familiar, "Do not believe in yourself until the day you die" (Avot, 2,5), but they also quote from tractates of the Babylonian Talmud such as Shekalim, Ketubut, Yevamoth, and Sanhedrin, among others. I heard quotes from the prayer book, the Siddur, since girls and young women usually say morning prayers at school, and even busy married women with many children say one short prayer a day, usually Mincha (the afternoon prayer), and are therefore familiar with these texts. Moreover, there were midrashic quotes from Tana Devei Eliyahu and Leviticus Raba, among others, which are beyond the bounds of their curricula. The sheer number of books that I had to open to find the references to their responses reflects the richness of the knowledge these women possess. Some of the responses in the questionnaires resembled a part of a lecture or a piece of Responsa - the halakhic question and answer literature.

The fact that ultra-Orthodox women use religious discourse makes sense. Even though they are not allowed to sit in the "Beit Midrash", the religious place of study, and learn the Talmud, they are exposed to halakhic and midrashic discourse in school, in their ongoing communal learning, and from the men in their lives, rabbis, fathers, husbands and sons. These data demonstrate the sheer quantity, quality and availability of this discourse. Their 
answers reflect not only the richness of their knowledge, but also their ability to retrieve it and apply it naturally and easily in multiple formats.

This study argues that this discourse actually demonstrates the ultra-Orthodox women's agency. With their combined religious and secular education, and work that is primarily outside the home, many of them are principal breadwinners. I reiterate my belief that this discourse is part of their highly intelligent navigation between their simultaneous roles as both gatekeepers and change agents.

Their rich and detailed answers reflect their need to demonstrate that they practise not simply what they are told to do, but rather that their practices are ideological, based on religious texts and discourses. I suggest that this is a surreptitious way of using their agency, not against the men, but in order to show that their obedience is inherently thoughtful and based on rules they understand and approve of. This everyday halakhic discourse used by ultra-Orthodox women illustrates the combination of sacred and profane that is reflected in their lived religion. Ostensibly, ultra-Orthodox women enter the men's symbolic sphere via their discourse. But the discourse used by these women is not that of the society of the male Beit Midrash. Their conversations describing the media through religious terminology creates a new combination connecting the traditional with the modern, and the sacred with the profane. This combination is evident in almost all the responses and could be illustrated as a reverse usage of Wuthnow's (2011) description of "code switching and register shifts through which religious people translated religious motives into nonreligious language" (9).

By reversing this process, ultra-Orthodox women translate nonreligious tools into religious language. They use the term "ascend in holiness and do not descend", as an imperative that brings them ever closer to godliness. This meaningful mixing can be understood using Casanova's $(2009,19)$ insights about the "deprivatization of religion". He describes a two-directional movement, with "religious actors bringing religious norms into the secular public space" and vice-versa. Though ultra-Orthodox men exclude women from the Beit Midrash, ultra-Orthodox women use religious terminology and tools to describe their relationships with the media, one of many symbolic segments of the modern world.

At the beginning of the article, I asked whether these women use this discourse for negotiation. Some of them do, particularly Tehila and Yokheved. They address the need while being aware of the danger at the same time. But there is something more important than negotiation, and even more important than agency creation. Babcock suggests that there are more aspects of symbolic inversion, which "remind us of the arbitrary condition of imposing an order on our environment and experience, even while they enable us to see certain features of that order more clearly, simply because they have turned in-sight [sic!] out" (Babcock 1978, 29).

The women point out this arbitrary condition of religious discourse by mirroring male discourse and control in their own easy adoption and adaptation of it. The ultra-Orthodox men dedicate their lives to be scholars (Friedman 1991). The women, however, assimilate the religious language very quickly and use it daily throughout their busy lives. They combine the sacred and the profane inside their homes and big families and in their full-time jobs outside. They have no need to enter the Beit Midrash or refer explicitly to the control men have over the religious discourse. They simply use it themselves easily, applying it to their everyday needs. I view their appropriation strategy as having multiple levels of sophistication that reflects far more than just agency. 
The contribution of this article derives not only from the description of various religious terms within the discourse of ultra-Orthodox women, but also from the agency these women create for themselves through this usage. Many of the texts which the women used here are outside of their formal curricula, particularly those deriving from the Talmud. This did not, however, interfere with their obtaining this knowledge from other sources, retaining and applying it even for such a mundane and relatively secular exercise as responding to a questionnaire about media use. This is a reflection of their ability to undermine the existing order by using religious discourse for their day-to-day religious lives without having to apply to the men, the formal "owners" who control this discourse, for permission.

The issues addressed here need to be investigated with larger samples including ultraOrthodox men, as well as with more significant comparisons between genders among other religious communities. It is also necessary to seek these women's voices regarding their intentions. In-depth interviews would enable us to see if this discourse is a part of a rebellious conciseness, social development and distribution of language and discourse, or something else. However, with or without feminist intention or even the wish to change the order of things, the discourse of these women is part of the inevitable change that has occurred within the intelligent and educated community of ultra-Orthodox women.

\section{Notes}

1. https://halakhah.com/bababathra/bababathra_60.html

2. http://www.taggedtanakh.org/Chapter/Index/english-Num-24

3. http://www.taggedtanakh.org/Chapter/Index/english-Prov-7

4. https://www.chabad.org/library/article_cdo/aid/2011/jewish/Chapter-Two.htm

\section{Disclosure statement}

No potential conflict of interest was reported by the author.

\section{Notes on contributor}

Dr. Rivka Neriya-Ben Shahar is a senior lecturer at Sapir Academic College in Sderot, Israel, teaching courses in research methods, communication, religion, and gender. Her doctorate at the Hebrew University of Jerusalem was entitled "Ultra-Orthodox Women and Mass Media in Israel - Exposure Patterns and Reading Strategies." She was a Fulbright post-doctoral fellow and a Scholar in Residence at the Hadassah-Brandeis Institute at Brandeis University. She worked on a study that analyses women's cultural-religious praxes. Dr. Neriya Ben-Shahar researches the mass media from the perspectives of religion and gender. Her most recent research project addresses the tension between religious values and new technologies among Old Order Amish women and Jewish ultra-Orthodox women.

\section{References}

Abu-Lughod, Lila. 1990. “The Romance of Resistance: Tracing Transformations of Power Through Bedouin Women.” American Ethnologist 17 (1): 41-55. 
Abu-Lughod, Lila. 1991. "Writing Against Culture." In Recapturing Anthropology: Working in the Present, edited by Richard G. Fox, 62-137. Santa Fe: School of American Research Press.

Abu-Lughod, Lila. 2013. Do Muslim Women Need Saving? Cambridge: Harvard University Press. Almond, Gabriel A., Scott R. Appelby, and Emmanuel Sivan. 2003. Strong Religion: The Rise of Fundamentalisms Around the World. Chicago: University of Chicago Press.

Ammerman, Nancy T. 2007. Everyday Religion. New York: Oxford University Press.

Asad, Talal. 2003. Formations of the Secular: Christianity, Islam, Modernity. Stanford: Stanford University Press.

Avishai, Orit. 2008. “'Doing Religion' in a Secular World: Women in Conservative Religions and the Question of Agency." Gender \& Society 22: 409-433.

Babcock, Barbara A. 1978. "Introduction." In The Reversible World: Symbolic Inversion in Art and Society, edited by Barbara A. Babcock, 13-38. Ithaca: Cornell University Press.

Cahaner, Lee, Dilad Malach, and Maya Choshen. 2017. The Yearbook of Ultra-Orthodox Society in Israel. Jerusalem: The Israel Democracy Institute. [In Hebrew].

Campbell, Heidi A. 2010. When Religion Meets New Media. London: Routledge.

Caplan, Kimi. 2007. The Internal Popular Discourse in Israeli Haredi Society. Jerusalem: Zalman Shazar Center for Jewish History. [In Hebrew].

Casanova, Jose. 2009. Religion, Politics and Gender Equality: Public Religions Revisited. [Draft Working Document]. Geneva: United Nations Research Institute for Social Development.

Casanova, Jose. 2010. Secularisation, Religion and Multicultural Citizenship. Public lecture within the symposium Islamic theology in dialogue, University of Hamburg, January 14-15.

Douglas, Mary. 1966. Purity and Danger: An Analysis of Concepts of Pollution and Taboo. London: Routledge \& Kegan Paul.

Douglas, Mary. 1970. Natural Symbols: Explorations in Cosmology. London: Routledge.

Douglas, Mary. 2005. A History of Grid and Group Cultural Theory. Paper presented at lecture in University of Toronto, available online: http://projects.chass.utoronto.ca/semiotics/cyber/ douglas1.pdf.

El-Or, Tamar. 1994. Educated and Ignorant: Ultra-Orthodox Jewish Women and Their World. Boulder, CO: Rienner.

Fader, Ayala. 2009. Mitzvah Girls: Bringing Up the Next Generation of Hasidic Jews in Brooklyn. Princeton, NJ: Princeton University Press.

Fader, Ayala. 2013. “Non-Liberal Jewish Women's Audiocassette Lectures in Brooklyn: A Crisis of Faith and the Morality of Media." American Anthropologist 115 (1): 72-84.

Foucault, Michel. 1969. The Archeology of Knowledge: And the Discourse on Language. New York: Pantheon Books.

Foucault, Michel. 1981. “The Order of Discourse.” In Untying the Text: A Post-Structuralist Reader, edited by Robert Young, 48-78. Boston: Routledge.

Friedman, Menachem. 1991. Haredi Society: Sources, Trends and Processes. Jerusalem: Jerusalem Institute for Israel Studies. [In Hebrew].

Friedman, Yisraela, Nava Shaul-Mena, Nir Fogel, et al. 2011. Measurement and Estimates of the Population of Ultra-Orthodox Jews. Jerusalem: Central Bureau of Statistics. [In Hebrew].

Griffith, Marie R. 1997. God's Daughters: Evangelical Women and the Power of Submission. Berkeley: University of California Press.

Hill Collins, Patricia. 1986. "Learning From the Outsider Within: The Sociological Significance of Black Feminist Thought.” Social Problem 33 (6): S14-S32.

Hill Collins, Patricia. 2000. "Gender, Black Feminism and Black Political Economy." Annals of the American Academy of Political and Social Science 568: 41-53.

Inbari, Motti. 2016. Jewish Radical Ultra-Orthodoxy Confronts Modernity, Zionism and Women's Equality. New York: Cambridge University Press.

Jacobson, Shari. 2006. "Modernity, Conservative Religious Movements, and the Female Subject: Newly Ultra-Orthodox Sephardi Women in Buenos Aires." American Anthropologist 108 (2): 336-346.

Lee, Raymond M. 1993. Doing Research on Sensitive Topics. London: Sage. 
Luhrmann, Tania M. 2012. When God Talks Back: Understanding the American Evangelical Relationship with God. New York: Vintage Books.

Mahmood, Saba. 2005. The Politics of Piety: The Islamic Revival and the Feminist Subject. Princeton, NJ: Princeton University Press.

Marty, Martin, and Scott Appleby, eds. 1991. Fundamentalisms Observed. Chicago: University of Chicago Press.

McGuire, Meredith B. 2008. Lived Religion: Faith and Practice in Everyday Life. Oxford: Oxford University Press.

Orsi, Robert A. 2005. Between Heaven and Earth: The Religious Worlds People Make and the Scholars Who Study Them. Princeton: Princeton University Press.

Orsi, Robert A. 2012. "Afterword: Everyday Religion and the Contemporary World: The UnModern, or What Was Supposed to Have Disappeared but Did Not." In Ordinary Lives and Grand Schemes: An Anthropology of Everyday Religion, edited by Samuli Schielke, and Lisa Debevec, 146-161. New York: Berghahn Books.

Pew Research Center. 2013. A Portrait of Jewish Americans. www.pewforum.org/files/2013/10/ jewish-american-full-report-for-web.pdf.

Radner, Joan N., and Susan S. Lanser. 1993. "Strategies of Coding in Women's Cultures." In Feminist Messages: Coding in Women's Folk Culture, edited by Joan Newlon Radner, 1-30. Urbana: University of Illinois Press.

Rier, David A., Avraham Schwartzbaum, and Chaya Heller. 2008. "Methodological Issues in Studying an Insular, Traditional Population: A Women's Health Survey among Israeli Haredi (Ultra-Orthodox) Jews." Women \& Health 48 (4): 363-381.

Schutz, Alfred. 1962. Collected Papers, I: The Problem of Social Reality. Lieden. Netherlands: Martinus Nijhoff.

Silber, Michael. 1992. “The Emergence of Ultra-Orthodoxy: The Invention of a Tradition.” In The Uses of Tradition: Jewish Continuity Since Emancipation, edited by Jack Wertheimer, 23-84. New York, Jerusalem: JTS.

Stadler, Nurit. 2009. Yeshiva Fundamentalism: Piety, Gender, and Resistance in the Ultra-Orthodox World. New York: New York University Press.

Stadler, Nurit. 2012. A Well-Worn Tallis for a New Ceremony: Trends in Israeli Haredi Culture. Brighton, MA: Academic studies Press.

Steinmetz, Simona, and Muhammad Haj-Yahya. 2006. "Definitions of and Beliefs About Wife Abuse among Ultra-Orthodox Jewish Men From Israel." Journal of Interpersonal Violence 21 (4): 525-554.

Stout, Daniel A. 2001. "Beyond Culture Wars: An Introduction to the Study of Religion and Popular Culture.” In Religion and Popular Culture: Studies on the Interaction of Worldviews, edited by Daniel A. Stout, and Judith M. Buddenbaum, 3-18. Ames: Iowa State University Press.

Wuthnow, Robert J. 2011. “Taking Talk Seriously: Religions Discourse as Social Practice.” Journal for the Scientific Study of Religion 50 (10): 1-21. 